\title{
Physiological and Psychological Effects of Listening To Holy Quran Recitation in the Intensive Care Unit Patients: A Systematic Review
}

\author{
Mohd Basri Mat-Nor ${ }^{a}$, Noor Airini Ibrahim ${ }^{b}$, Nur Fariza Ramly ${ }^{a}$, Fa'iza Abdullah ${ }^{c}$ \\ aDepartment of Anaesthesiology and Intensive Care, Kulliyyah of Medicine, International Islamic University \\ Malaysia, 25200 Kuantan, Pahang. \\ ${ }^{b}$ Anaesthesiology Unit, Department of Surgery, Faculty of Medicine and Health Sciences, Universiti Putra \\ Malaysia, 43400 Serdang, Selangor, Malaysia \\ 'Department of Family Medicine, Kulliyyah of Medicine, International Islamic University Malaysia, 25200 \\ Kuantan, Pahang.
}

\section{ABSTRACT}

Stress and anxiety are common among intensive care unit (ICU) patients especially those who are on mechanical ventilation. Non-pharmacological interventions such as music and prayer are recommended because they are opioid sparing, easy to provide, cheap and safe. There is a growing body of evidence on the effects of Holy Quran Recitation (HQR) in reducing stress and anxiety in critically ill Muslim patients. The aim of this review is to evaluate the physiological and psychological effects of HQR specifically in ICU setting. This review was performed on articles published between 2007 and 2018. Extensive search was done using PubMed, ISI Web of Knowledge, Scopus and Google Scholar. Systematic review articles are also assessed and relevant literatures are hand searched based on reference lists and citations made in key publications. Studies related to HQR which were done outside adult ICU setting were excluded. A total of nine articles are included in the final list for detail analysis. Findings of this review revealed six studies with significant results in improving stress responses, hemodynamic stability and conscious levels. HQR is a potential nonpharmacological tool to reduce stress and can also be used as auditory stimulus to improve conscious level in comatose patients. More studies in this area are recommended aiming for low risk of bias, appropriate calculation of sample size and adequately powered to detect significant outcomes.

KEYWORDS: stress, non-pharmacological, critically ill, mechanical ventilation, Holy Quran listening

\section{INTRODUCTION}

Stress and anxiety are common among mechanically ventilated intensive care unit (ICU) patients. ${ }^{1}$ Lusk and Lash categorised ICU stressors into psychological, treatment-related and environmental. ${ }^{2}$ If left untreated, it increases the sympathetic tone and induces stress response by stimulating the hypothalamus-pituitary-adrenal axis response. Stress may impede the process of healing and complicates the weaning process, thus prolong

Corresponding Author:

Assoc. Prof. Dato' Dr. Mohd Basri Mat Nor, Department of Anaesthesiology and Intensive Care, Kulliyyah of Medicine, International Islamic University Malaysia, 25200 Kuantan, Pahang, Malaysia

Tel : +6095912610

Email: m.basri@iium.edu.my the period of MV and ICU stay. ${ }^{3}$ Unnecessary analgo-sedative medications may increase risk of over sedation with undesirable side-effects. As a result, 2018 Society of Critical Care Medicine Guidelines for the management of pain, agitation and delirium in the ICU recommend nonpharmacological interventions, because they are opioid-sparing, easy to provide, cheap and safe. ${ }^{4}$ Complimentary therapies to relieve stress, agitation and anxiety include music therapy, nature-based sound, prayer, massage and Quran listening. In a prospective randomized controlled trial (RCT) among 373 ICU patients receiving ventilator support, patient-directed music listening resulted in greater reduction in anxiety, sedation frequency and intensity compared with usual care. ${ }^{5}$

Clinical trials looking at spiritual approach in dealing with the emotional problems among ICU is hardly 
available. Plakas et al found that spiritual care which concerns with religiosity, prayer and faith to God has been used in coping with health related problems. Rath, and Anastasi \& Newberg have found that listening to intercessory prayer recitation is able to enhance positive physiological changes among critically ill Christian patients. ${ }^{6,7}$ Whereas, Fisher introduced meditation session to reduce patients' anxiety and distress among hospitalised patients. ${ }^{8}$ Levin and Chatters stated that results of several studies have been consistent in indicating a salutary relationship between religious involvement and health status. ${ }^{9}$

There is a growing trend of studies on the effect of Holy Quran recitation (HQR) to reduce stress in hospitalised patients such as during labour, ${ }^{10}$ during hemodialysis, ${ }^{11}$ prior to invasive procedures and prior to induction of anaesthesia and surgeries. ${ }^{12,13}$ In a recent systematic review (SR) of 28 RCTs and quasi-experiments, Ghiasi \& Keramat revealed a positive effect to $H Q R$ on anxiety in various settings. ${ }^{14}$ Therefore, there is a potential role of $\mathrm{HQR}$ in reducing stress and anxiety in the critically ill patients. The aim of this SR is to evaluate the physiological and psychological effects of $H Q R$ among critically ill patients in the ICU setting.

\section{MATERIALS AND METHODS}

The strategy for searching related articles was using PubMed, ISI Web of Knowledge, MEDLINE, Scopus, Al -Quran \& Medicine and Google Scholar. Key words and MeSH terms such as Quran, listening, recitation, anxiety, stress, critically ill patients, ICU and Boolean operators "AND" and "OR" were used. The search was limited to original articles available in English from January 2007 to December 2018. Abstracts of the articles were searched and only those related to Quran and ICU settings were selected. We also evaluated SR articles that discussed the effects of Quran on anxiety and health to search for potential articles. Professional journals were hand searched for relevant literatures based on the reference lists and citations made in key publications. Studies related to $\mathrm{HQR}$ and its effects which were done outside ICUs e.g. general wards, operating rooms, labour wards or catheter laboratories were excluded. Only clinical trials and quasi-experiments done in patients aged more than 18 years old were chosen for final analysis. The eligibility of papers that met the inclusion criteria were discussed among reviewers and any disagreements were resolved by discussion. The following information were extracted from the articles: title, authors, year of publication, study objectives, setting, methodology, participants, assessment tools, outcome measures, key findings and conclusions. The risk of bias was assessed using the modified Cochrane Collaboration Risk of Bias Tool, which consists of selection, performance, attrition, reporting and detection bias. Each domain was assessed as a judgment of high, low or unclear risk of bias. ${ }^{15}$

\section{RESULTS}

Figure I summarised the flow chart used to retrieve the included articles. A total of nine out of 15 shortlisted articles were selected for a more detailed review. Six papers were excluded for the following reasons; one was a replication of another study published in a different journal, neither full article nor abstract was retrievable in two studies, one study was a conference material without full article and the last two did not use Quran verses. The final list consists of four RCTs and five quasiexperimental studies as shown in Table 1. Seven were conducted in general ICUs and the other two in coronary care ICUs. Eight studies involved mechanically ventilated patients and one without artificial ventilation at any stage. Most of the studies were conducted in Iran $(n=4)$, followed by Malaysia $(n=2)$, Indonesia (1), Egypt $(n=1)$ and Saudi Arabia (1). Six studies demonstrated significant results, meanwhile the other three showed no significant findings.

\section{Study Characteristics}

The characteristics of nine articles which are selected for final analysis are summarised in Table 2. The total number of critically ill patients involved was 360. Seven studies were done in between 2017 and 2018; two were conducted in 2014 and one in 2013. Study designs were a two-arm parallel group (6) and a single-arm group (3). Three studies assessed the effects of HQR on physiological response to stress, four studies assessed the effects on vital signs and conscious level, one study on the hemodynamic changes and one study evaluated the effects on weaning from MV. The chapters used in the studies were Al-Fatehah and Yasiin (4), AlBaqarah (2), Ar-Raad (1), Yusof (1) and one has no documentation. 


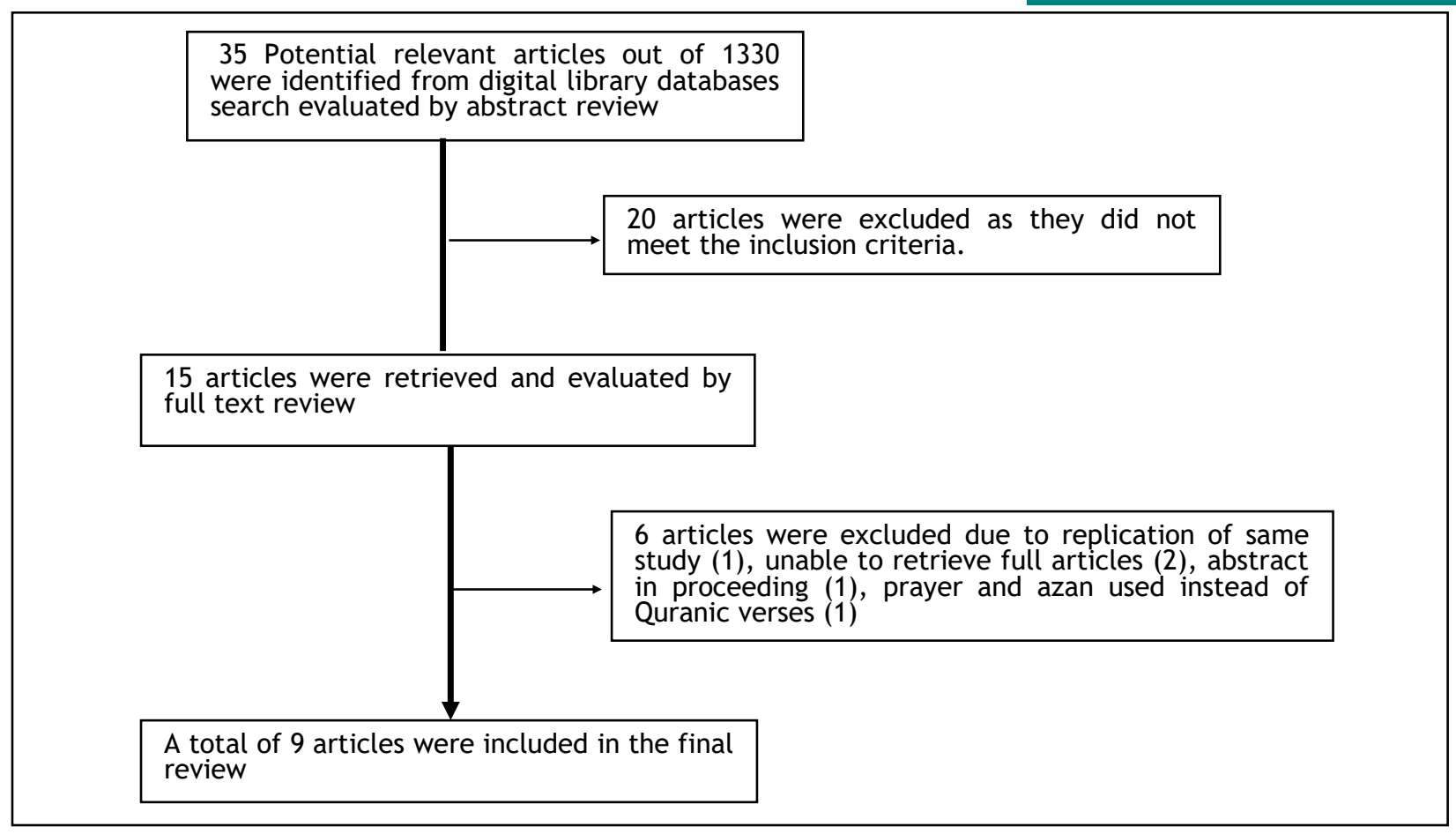

Figure 1: Flow diagram of literature search results

Holy Quran recitation in intensive care patients with no effects on clinical outcome

A total of three studies revealed no effects on clinical outcomes and all involved mechanically ventilated patients. Ariff et al assessed five patients in a one-arm pilot study in a coronary intensive care, looking at haemodynamic changes from Yasiin recitation. ${ }^{16}$ This is the only study utilised the 'live' voice of Quran, recited by a person at the bedside. The mean arterial pressure (MAP), pulse rate (PR), $\mathrm{SpO}_{2}$ and ECG were not different at baseline and post-intervention. There were no strict inclusion or exclusion criteria mentioned and no documentation of control of the important confounders (e.g. inotropic support, sedation or cardiac medications) which might expose the study to bias. The study was intended to assist in constructing a methodological approach in assessing the therapeutic effect of Surah Yasiin on patients' hemodynamic. In a repeated measures quasi-experimental study, Abu Bakar alternately assigned $44 \mathrm{ICU}$ patients into $\mathrm{HQR}$ and control groups to compare their physiological changes. ${ }^{17}$ The intervention group had a 30 minutes listening to Surah Al-Fatehah and Yasiin, and participants in both groups were located in quiet rooms. The PR, blood pressure (BP), $\mathrm{SpO}_{2}$ and tidal volume were measured. The results showed no significant changes in MAP, systolic BP, diastolic BP and tidal volume, except in PR.
In a pilot study conducted in Saudi Arabia, Yadak randomised 55 critically ill patients into two groups during weaning from ventilator prior to spontaneous breathing trials (SBTs). ${ }^{18}$ The intervention group listened to Surah Al-Baqarah for 30 minutes, whereas the control group were put on headphones without the Quran. The physiological and weaning parameters were compared. There were no significant differences in both groups and the investigators concluded that there were no negative effects of HQR on weaning. This was the first study done to explore the possible utility of HQR in ICU patients during weaning process.

\section{Holy Quran Recitation listening associated with better clinical outcomes}

Six studies in this review showed positive effects, of these, three studies evaluated the effect of HQR on improvement of conscious levels. In a double blind RCT, Naseri-Salahshour randomized 66 patients into Quran listening and control. ${ }^{19}$ Patients included were opioids abuse, head trauma and intracerebral haemorrhages. The samples were homogenous in terms of level of consciousness and causes of coma. The intervention along with the standard care was conducted daily for ten days. They found that the level of consciousness in the intervention group increased significantly on day ten. In a one-arm study, Nasiri evaluated 30 ICU patients with GCS 8 to 
Table 1: Final list of studies included in the systematic review

Title, Journal and Year of publication

1.* The Effect of Listening to Holy Quran Recitation on Weaning Patients Receiving Mechanical Ventilation in the Intensive Care Unit: A Pilot Study. J Relig Health, 2017

2.* $\quad$ Effects Of Holy Quran Listening On Physiological Stress Response Among Muslim Patients In Intensive Care Unit. J Manag Muamalah, $2014^{17}$

3.* Pilot Study on the Effect of Yasiin Recitation on the Haemodynamics of Ventilated Patients. Int Med J Malaysia, 2013 ${ }^{16}$

4. The effect of religious intervention on the level of consciousness of comatose patients hospitalized in an intensive care unit: a randomized clinical trial. Eur J Integr Med, $2018^{19}$

5. An Investigation into the Effect of Listening to the Voice of the Holy Quran on Vital Signs and Consciousness Level of Patients Admitted to the ICU Wards of Zabol University of Medical Sciences Hospitals. Middle East J Fam Med, $2017^{20}$

6. The Effect Of Holy Quran Recitation Sound On Vital Signs And Arterial Oxygen Pressure Of Unconscious Patients Hospitalized In ICU. IAJPS, $2017^{22}$

7. The Effect of Listening to Quran on Physiological Responses of Mechanically Ventilated Muslim Patients. IOSR J Nurs Heal Sci, $2017^{21}$

8. Effect of Comfort Care Integrated with the Holy Qur'an Recitation on Comfort of Muslim Patients under Mechanical Ventilation: A Pilot Study. Med Surg Nurs J, $2017^{23}$

9. The Effect of Simultaneous Aromatherapy and Quran Recitation on Anxiety Level of Patients with Myocardial Infarction. Complement Med J, $2014^{24}$

\section{Authors, Country where the research done}

M Yadak, KA Ansari et al.

Saudi

SA Abu Bakar. MALAYSIA

Arif MS et al. MALAYSIA

V Naseri-Salahshour et al.

IRAN

\author{
AA Nasiri, H Shahdadi \\ et al. \\ IRAN
}

\section{R Mirzaeian et al. IRAN}

MM El-Hady and NA

Kandeel

EGYPT

JS Rustam, W
Kongsuwan et al.
INDONESIA
Z Najafi, Z Tagharrobi
et al.
IRAN

Outcomes, number of patients, study design

No difference, $\mathrm{N}=55$

Clinical trial

No difference, $\mathrm{N}=44$

Quasi-experimental

No difference, $\mathrm{N}=5$

Quasi-experimental

Positive, $\mathrm{N}=66$

Clinical trial

Positive, $\mathrm{N}=30$

Clinical trial

Positive, $\mathrm{N}=20$

Quasi-experimental

Positive, $N=60$

Quasi-experimental

Positive, $\mathrm{N}=10$

Quasi-experimental

Positive, $\mathrm{N}=70$

Clinical trial

Legend: * The articles demonstrated no significant results.

10 after listening to Surah Yusof for 15 minutes daily for ten consecutive days. ${ }^{20}$ Patients included must not receive intravenous sedation, no bleeding or neurosurgery in temporal region, no history of brain damage and no drug addiction. There were significant differences observed in the vital signs comprising of $\mathrm{BP}, \mathrm{HR}$ and respiratory rate before and after intervention, with also significant improvement in the level of consciousness before and after intervention. In the Egypt study, El-Hady included 60 patients from trauma ICUs with GCS of 9 to 12 and stable hemodynamic from three different hospitals. ${ }^{21}$ The study design was quasi experimental, and Surah Al-Baqarah was played for 60 minutes in the intervention $\operatorname{arm}(\mathrm{N}=30)$. James adaptation of GCS was used to assess the level of consciousness. There were significant differences in vital signs as compared to control group but most importantly, there was also a significant increase in GCS and pupil reaction to light immediately after listening to Quran.

Mirzaeian investigated the effects of Quran recitation as a tranquilizer on vital signs and arterial oxygen pressure in 20 unconscious ICU patients. ${ }^{22}$ The Quran group listened to Surah Yasiin daily via MP3 recorder and headphones for four weeks. After interventions, mean BP and arterial oxygen pressure had significant differences compared to baseline. In a pilot study conducted in Indonesia, 10 critically ill patients on MV from two ICUs were recruited. Surah Al-Fatehah and Surah Yasiin were played for 15 minutes for three days. ${ }^{23}$ This was a single arm quasi experimental pretest-posttest study. Modified version of shortened general comfort questionnaire (SGCQ) was used to evaluate comfort. The mean 
score of SGCQ was increased significantly after receiving the comfort care integrated with AlQuran. The last study that showed positive results in this review examined the effect of both HQR and aromatherapy in patients with acute myocardial infarction in a coronary ICU. ${ }^{24}$ Seventy patients were randomized equally into case and control groups. Quran recitation was played four times a day for two days and Spielberg anxiety questionnaire (SAQ) was used to measure anxiety level. There was statistical difference in the SAQ mean score between case and control groups after intervention in every four cycle.

\section{Risk of bias in included studies}

Figure II summarised the "Risk of bias" of all included studies. From the nine trials included in the study, three were RCTs. However, only NaseriSalahshour ${ }^{19}$ reported details of randomisation method used while none was mentioned for Yadak and Najafi. ${ }^{18,24}$ There were steps taken in these studies to provide allocation concealment and blind the participant and outcome assessors making them again the only three considered low risk for allocation concealment. In the studies by Nasiri ${ }^{20}$ and Mirzaeian ${ }^{22}$ we were not able to assess selection, performance and attrition bias. Rustam ${ }^{23}$ and Ariff ${ }^{16}$ used relatively small samples but most studies were judged to have a low risk of bias for incomplete outcome data, having no or minimal participant losses. Most studies included were free of selective outcome reporting and other potential sources of bias

\section{DISCUSSION}

There are limited numbers of clinical trials looking at the evidence of physiological and psychological effects of HQR in critically ill patients. Nine articles are included in the final analysis; of which eight included mechanically ventilated patients and majority of the studies were conducted in Iran. Four of them assessed HQR as non-pharmacological tool to reduce stress; three studies assessed its effects on conscious level and two studies on haemodynamic parameters of coronary care patients. Even though six of them showed promising results, it is difficult to draw conclusion due to following reasons; flaws in methodologies, inadequate power and calculation of sample size and unclear implementation of RCT process on steps to reduce bias in order to ensure the quality of the study outcome.

The understanding of the meaning of Quran may influence the results of the study. Based on this argument, the results would be different if it was conducted in non-Arabic speaking patients. Jabbari et al randomised 168 pregnant women into three groups; one listened to Quran recitation with translation, one listened to Quran without

\begin{tabular}{|c|c|c|c|c|c|c|c|c|c|}
\hline & $\begin{array}{l}\text { Yadak } \\
2017\end{array}$ & $\begin{array}{l}\text { Abu } \\
\text { Bakar } \\
2014\end{array}$ & $\begin{array}{l}\text { Ariff } \\
2013\end{array}$ & $\begin{array}{l}\text { Naseri- } \\
\text { Salahsour } \\
2018\end{array}$ & $\begin{array}{l}\text { Nasiri } \\
2017\end{array}$ & $\begin{array}{l}\text { Mirzaeian } \\
2017\end{array}$ & $\begin{array}{l}\text { El-Hady } \\
2017\end{array}$ & $\begin{array}{l}\text { Rustam } \\
2017\end{array}$ & $\begin{array}{l}\text { Najafi } \\
2014\end{array}$ \\
\hline $\begin{array}{l}\text { Random Sequence } \\
\text { Generation (Selection } \\
\text { Bias) }\end{array}$ & & & & & & & & & \\
\hline $\begin{array}{l}\text { Allocation } \\
\text { Concealment } \\
\text { (Selection Bias) }\end{array}$ & & & & & & & & & \\
\hline $\begin{array}{l}\text { Blinding of } \\
\text { participants } \\
\text { (Performance Bias) }\end{array}$ & & & & & & & & & \\
\hline $\begin{array}{l}\text { Blinding of outcome } \\
\text { assessment } \\
\text { (Detection Bias) }\end{array}$ & & & & & & & & & \\
\hline $\begin{array}{l}\text { Incomplete Outcome } \\
\text { Data (Attrition Bias) }\end{array}$ & & & & & & & & & \\
\hline $\begin{array}{l}\text { Selective Reporting } \\
\text { (Reporting bias) }\end{array}$ & & & & & & & & & \\
\hline
\end{tabular}

Figure 2 : "Risk of bias" summary of included studies 
translation and these were compared with a control group. ${ }^{25}$ This study confirmed that listening to HQR with or without translation was effective in alleviating intensity of stress, anxiety and depression. Since music therapy has been proven empirically as an effective complimentary therapy in critically ill patients, the calmness and relaxation effects of HQR could be due to the melodious voice of the sounds of Quran. Nakhavali \& Seyedi mentioned that the poetic contents and rhythmic recitation of Quran are pleasing to the ear of each listener, even to unaccustomed and non-Arabic persons. ${ }^{26}$ However, Mahjoob et al found that there were positive effects on mental health even if the Quran was recited without its musical tone. ${ }^{27}$ Momtahan et al wrote "one of the aspects of the Quran which has been little studied is the miracle which lies in its music and phonetic order". The effects that arise from Quran recitation come from the structure rather than the content, with its sound, words and pleasant music rather than from meanings and valuable content incorporated in it. ${ }^{28}$ The chapters chosen may play an important role in the local community of the population studied. According to previous studies, surah al-Fatehah and Yasiin, is regarded as an infallible aid in healing and it has been used widely in Malay-Muslim for incantation by most Malay-Muslim Islamic Healer. ${ }^{29}$

A few studies looked at the effects of HQR and music on electroencephalogram (EEG). The analysis of the results showed that listening to $H Q R$ in healthy volunteers can generate alpha waves which promote relaxation as compared with resting and listening to music. ${ }^{30,31}$ Zulkurnaini et al investigated and compared listening to Quran with classical music on EEG before, during and after interventions. Significant alpha band increment in the Quran group (12.67\% vs. 9.96\%) prompted them to conclude that Quran listening is more relaxing than classical music. ${ }^{32}$

The beneficial effects of auditory stimulation on enhancement of consciousness were emphasized in some studies. ${ }^{28,33,34}$ Three studies in this current review supported the evidence that auditory stimulation by Quranic sound could improve the level of consciousness of comatose patients. Disorders of consciousness are characterised either by alteration in the level or by content of consciousness. Since hearing is the strongest sensation of the five senses and the last sensation that is lost in comatose patients, Quranic voice can be used to provide the spiritual needs of hospitalised Muslim patients. Oh et al carried out a study "on the impact of stimulus on improving comatose patients" and found that at least two weeks was required for the onset of sensory stimulation impact. ${ }^{35}$ Studies (5) and (6) played the Quran 15-17 minutes daily for ten days and Mirzaeian ${ }^{22}$ played Quran 15 minutes daily for 4 weeks, to observe progressive improvement in conscious levels. Mirzaeian also showed positive effects of auditory stimulus through HQR on haemodynamic and vital signs stability in unconscious patients.

There are some limitations of the studies above. The ideal settings for HQR listening in ICU were difficult to achieve because the researchers had to eliminate noise as another auditory stimuli even when headphones were used. The sources of noise could be either operational or structural. ${ }^{36}$ ICU noise levels should ideally be measured and patients are isolated in quiet rooms ${ }^{17}$ during intervention period. The use of noise cancelling headphones can be as good as music in reducing stress. In a RCT by Chlan et al, among ICU patients receiving ventilator support, patient-directed music resulted in greater reduction in anxiety compared with usual care, but not compared with noise-cancelling headphone groups. $^{5}$

Furthermore, confounders that may increase or decrease the value of vital signs such as effects of vasopressors, drugs, non-resolving acute illness and sepsis should be minimised in the study design. Most of the studies did not compare the SOFA, baseline APACHE II or SAPS II scores to quantify severity of illness. These baseline indicators should be evaluated prior to the intervention as they may influence the observed physiological parameters. Ideally, sedatives must be kept to a minimum so that attentiveness towards HQR intervention may be optimised. Other forms of medical procedures such as endotracheal tube suctioning, should also be minimised. Yadak included critically ill patients who were ready for SBTs. ${ }^{18}$ Patients who were ready for SBT usually would have fulfilled weaning criteria, achieved clinical cure and recovered from underlying acute illness. They were also more alert, and free from sedative agents or vasopressors. These conditions were quite ideal when comparing the physiological effects of HQR between experimental and control groups. Additional 
biomarkers such as procalcitonin could be measured to rule out the presence of bacterial sepsis. For the benefits of the future study, a more prolonged period of Quran intervention is recommended in order to yield more effective results. Other aspects to explore include the effects of familiarity of the surah, the freedom to choose favourite surah, recitation of the surah by familiar voice of family members ${ }^{28}$ and monitoring of changes in brainwaves by using EEG.

\section{CONCLUSION}

There is growing body of evidence that spirituality is an essential component of patient care in the ICU. Clinical trials on the effects of HQR in critically ill patients are quite challenging to perform since it is difficult to quantify the effects of physiological parameters while separating the possible influence of confounding factors. Our review reveals that the research in this area is scarce; however the evidence of $\mathrm{HQR}$ listening as a potential non-pharmacological tool to reduce anxiety and stress in Muslim ICU patients is increasing. In addition, HQR may be used as auditory stimulus in comatose patients in an attempt to improve their conscious level. We recommend more clinical trials should be conducted in future; aiming for low risk of bias, appropriate calculation of sample size and adequately powered to detect significant outcomes. Meanwhile, HQR listening is a safe, widely available and cheap intervention that may be included as a complementary therapy for anxiety in critically ill patients to achieve improved outcome.

Table 2: Characteristics of Included Studies

\begin{tabular}{|c|c|c|c|c|c|c|}
\hline & $\begin{array}{l}\text { First author, } \\
\text { Publication } \\
\text { year }\end{array}$ & $\begin{array}{l}\text { Type of study, } \\
\text { Population and } \\
\text { sampling }\end{array}$ & $\begin{array}{l}\text { Intervention and } \\
\text { comparison }\end{array}$ & Tool & Assessment & $\begin{array}{l}\text { Findings and } \\
\text { Conclusion }\end{array}$ \\
\hline 1. & $\begin{array}{l}\text { Yadak M et al. } \\
2017^{18} \\
\text { Objective: The } \\
\text { effect of } \\
\text { listening to HQR } \\
\text { as a non- } \\
\text { pharmacologi- } \\
\text { cal intervention } \\
\text { during weaning }\end{array}$ & $\begin{array}{l}\text { Design: Pilot study, } \\
\text { RCT, two arms. } \\
2015-2016 \\
\text { Mechanically ventilat- } \\
\text { ed patients, during } \\
\text { weaning } \\
\text { Calculated sample } \\
\text { size: } 94\end{array}$ & $\begin{array}{l}55 \text { patients } \\
\text { Case: } \mathrm{N}=32, \mathrm{MP} 3 \\
\text { Quran via } \\
\text { headphones for } 30 \\
\text { mins } \\
\text { Control: } \mathrm{N}=23 \text {, } \\
\text { Headphones with } \\
\text { eyes closed, ipod } \\
\text { off. }\end{array}$ & $\begin{array}{l}\text { Surah Al- } \\
\text { Baqarah }\end{array}$ & $\begin{array}{l}\text { Clinical parame- } \\
\text { ters: RR, HR, } \\
\text { SpO2, ETCO2, } \\
\text { BP } \\
\text { Monitoring: at } \\
\text { baseline, 5 } \\
\text { minute intervals } \\
\text { during } \\
\text { intervention and } \\
5 \text { min after } \\
\text { completion. } \\
\text { Weaning param- } \\
\text { eters: RBSI, } \\
\text { NIF, PS level, VT }\end{array}$ & $\begin{array}{l}\text { Findings: No } \\
\text { significant difference } \\
\text { between } 2 \text { groups } \\
\text { This findings suggest } \\
\text { no negative effect of } \\
\text { HQR on weaning pa- } \\
\text { tients from MV in the } \\
\text { ICU }\end{array}$ \\
\hline 2. & $\begin{array}{l}\text { SA Abu Bakar. } \\
2014^{17} \\
\text { Objective: To } \\
\text { examine the } \\
\text { effects of lis- } \\
\text { tening to HQR } \\
\text { on the physio- } \\
\text { logical stress } \\
\text { response }\end{array}$ & $\begin{array}{l}\text { Design: Repeated } \\
\text { measures quasi- } \\
\text { experimental, two } \\
\text { arms in ICU patients } \\
\text { on MV } \\
\text { Sample size: Not } \\
\text { calculated }\end{array}$ & $\begin{array}{l}44 \text { ICU patients } \\
\text { Case: } \mathrm{N}=22 \text {, } \\
\text { Control } \mathrm{N}=22 \\
\text { Conducted after } \\
\text { all ward rounds } \\
\text { done, resting } \\
\text { environment. } \\
\text { Doors closed, } \\
\text { lights dimmed and } \\
\text { staff informed. } \\
\text { Patients were } \\
\text { instructed to } \\
\text { close eyes }\end{array}$ & $\begin{array}{l}\text { Al-Fatehah } \\
\text { and Yassin. } \\
\text { MP3 } \\
\text { recorder. } \\
30 \text { mins } \\
\text { session }\end{array}$ & $\begin{array}{l}\text { Physiological: } \\
\text { HR, BP, RR. And } \\
\text { Respiratory: } \\
\text { SpO2, VT, RR } \\
\text { Monitoring: at } \\
\text { baseline, 5 } \\
\text { minutes interval } \\
\text { and } 5 \text { minutes } \\
\text { after the } \\
\text { intervention } \\
\text { completed. }\end{array}$ & $\begin{array}{l}\text { Pretest-posttest score } \\
\text { mean differences } \\
\text { comparison showed } \\
\text { no significant differ- } \\
\text { ences in HR, sBP, } \\
\text { dBP, MAPand RR. The } \\
\text { intervention group } \\
\text { experienced no } \\
\text { reduction in } \\
\text { physiological re- } \\
\text { sponse except in HR. } \\
\text { Conclusion: HQR } \\
\text { not significantly } \\
\text { effects except in HR. }\end{array}$ \\
\hline 3. & $\begin{array}{l}\text { Ariff MS et al. } \\
2013^{16} \\
\text { Objective: To } \\
\text { evaluate } \\
\text { therapeutic } \\
\text { effects of Yasiin } \\
\text { recitation on } \\
\text { hemodynamics } \\
\text { of critically ill } \\
\text { patients. }\end{array}$ & $\begin{array}{l}\text { Design: Pilot study, } \\
\text { one arm, quasi- } \\
\text { experimental of CCU } \\
\text { patients on MV } \\
\text { Sample size: Not cal- } \\
\text { culated }\end{array}$ & $\begin{array}{l}\text { Yasiin recited } \\
\text { twice. First by the } \\
\text { researcher, } \\
\text { followed by } \\
\text { relative. }\end{array}$ & Yasiin & $\begin{array}{l}\text { Mean blood } \\
\text { pressure, HR, } \\
\text { SpO2, ECG } \\
\text { changes. } \\
\text { Monitoring: at } \\
\text { baseline and } \\
\text { during } \\
\text { intervention at } \\
5 \text { minutes } \\
\text { interval }\end{array}$ & $\begin{array}{l}\text { The hemodynamic } \\
\text { parameters were not } \\
\text { significantly affected } \\
\text { by Yassin recitation. } \\
\text { Conclusion: Further } \\
\text { studies and } \\
\text { refinements of } \\
\text { methodology. }\end{array}$ \\
\hline
\end{tabular}




\begin{tabular}{|c|c|c|c|c|c|c|}
\hline & $\begin{array}{l}\text { First author, } \\
\text { Publication } \\
\text { year }\end{array}$ & $\begin{array}{l}\text { Type of study, } \\
\text { Population and } \\
\text { sampling }\end{array}$ & $\begin{array}{l}\text { Intervention and } \\
\text { comparison }\end{array}$ & Tool & Assessment & $\begin{array}{l}\text { Findings and } \\
\text { Conclusion }\end{array}$ \\
\hline 4. & $\begin{array}{l}\text { V Naseri- } \\
\text { Salahshour et } \\
\text { al. } 2018^{19} \\
\text { Objective: To } \\
\text { determine the } \\
\text { religious } \\
\text { intervention on } \\
\text { the level of } \\
\text { comatose } \\
\text { patients. }\end{array}$ & $\begin{array}{l}\text { Design: RCT, single } \\
\text { centre. } \\
\text { Population: ICU } \\
\text { patients, on MV } \\
\text { homogenous in term } \\
\text { of level of } \\
\text { consciousness and } \\
\text { coma. GCS } 3-5 \text {, } \\
\text { recruited } 48 \text { h after } \\
\text { hospitalization. } \\
\text { Sample size: Not } \\
\text { calculated }\end{array}$ & $\begin{array}{l}66 \text { comatose } \\
\text { patients } \\
\text { Case: Quran } \\
\mathrm{N}=33 \text {, for } 17 \\
\text { minutes daily for } \\
10 \text { days. } \\
\text { Control: } \mathrm{N}=33 \\
\text { (MP3 and head- } \\
\text { phones but no } \\
\text { quran) } \\
\text { Inclusion: severe } \\
\text { change in the } \\
\text { shape of face, } \\
\text { opioid poisoning, } \\
\text { head trauma, } \\
\text { intracerebral } \\
\text { haemorrhges. } \\
\text { Exclusion: pa- } \\
\text { tients discharged } \\
\text { before 10th day, } \\
\text { transfer to } \\
\text { another health } \\
\text { centre, surgery } \\
\text { after first } 24 h \text {, } \\
\text { death and } \\
\text { hearing } \\
\text { impairment }\end{array}$ & $\begin{array}{l}\text { Surah } \\
\text { Raad } \\
\text { GCS scale }\end{array}$ & $\begin{array}{l}\text { Level of } \\
\text { consciousness } \\
\text { i.e. GCS } \\
\text { components } \\
\text { eye opening, } \\
\text { verbal re- } \\
\text { sponse, motor } \\
\text { response } \\
\text { GCS measured } \\
\text { before and } \\
\text { after interven- } \\
\text { tion }\end{array}$ & $\begin{array}{l}\text { After } 10 \text { days, the } \\
\text { level of } \\
\text { consciousness in the } \\
\text { intervention group } \\
\text { increased } \\
\text { significantly } \\
(\mathrm{P}=0.01) \text {, the in- } \\
\text { crease in level of } \\
\text { consciousness in the } \\
\text { control group after } \\
\text { intervention ( } 10 \\
\text { days) was not } \\
\text { significant ( } \mathrm{P}=0.09) \\
\text { Conclusion: Quran } \\
\text { can improve the } \\
\text { level of comatose } \\
\text { patients. }\end{array}$ \\
\hline 5. & $\begin{array}{l}\text { AA Nasiri et al. } \\
2017^{20} \\
\text { Objective: To } \\
\text { investigate the } \\
\text { effect of Quran } \\
\text { on vital signs } \\
\text { and voice of } \\
\text { the Quran on } \\
\text { vital signs and } \\
\text { level of con- } \\
\text { sciousness }\end{array}$ & $\begin{array}{l}\text { Design: Single } \\
\text { centre, } \\
\text { Quasi-Elemental, } \\
\text { single arm. } \\
\text { Population: ICU } \\
\text { patients without } \\
\text { history of brain } \\
\text { damage, recruit at } \\
\text { least after } 24 \mathrm{~h} \text { of } \\
\text { stabilisation. } \\
\text { Sample size: not } \\
\text { calculated }\end{array}$ & $\begin{array}{l}30 \text { ICU patients } \\
\text { HQR Surah Yusof } \\
15 \text { minutes daily } \\
\text { for } 10 \text { days } \\
\text { Exclusion: critical } \\
\text { change in hemo- } \\
\text { dynamic or death } \\
\text { before } 10^{\text {th }} \text { day }\end{array}$ & $\begin{array}{l}\text { Surah } \\
\text { Yusof, } \\
\text { MP3 } \\
\text { recorder } \\
\text { via head- } \\
\text { phones }\end{array}$ & $\begin{array}{l}\text { Physiological: } \\
\text { BP, RR, HR } \\
\text { Consciousness } \\
\text { level } \\
\text { Monitoring: } 5 \\
\text { minutes prior } \\
\text { and immedi- } \\
\text { ately after } \\
\text { completion. }\end{array}$ & $\begin{array}{l}\text { Signifcant } \\
\text { differences were } \\
\text { observed }(\mathrm{p}<0.0001) \\
\text { BP, RR and HR } \\
\text { declined after } \\
\text { intervention. There } \\
\text { was a significant } \\
\text { difference between } \\
\text { the level of } \\
\text { consciousness before } \\
\text { and after the } \\
\text { intervention } \\
(p<0.0001) .\end{array}$ \\
\hline 6. & $\begin{array}{l}\text { R Mirzaeian et } \\
\text { al. } 2017^{22} \\
\text { Objective: To } \\
\text { investigate the } \\
\text { effect of HQR } \\
\text { as a tranquiliz- } \\
\text { er on vital } \\
\text { signs and arte- } \\
\text { rial oxygen } \\
\text { pressure on } \\
\text { unconscious } \\
\text { patients. }\end{array}$ & $\begin{array}{l}\text { Design: } \\
\text { Quasi-experimental } \\
\text { pretest-posttest } \\
\text { study, two hospitals, } \\
\text { two arms } \\
\text { Population: ICU } \\
\text { patients who were } \\
\text { almost homogenous } \\
\text { in terms of con- } \\
\text { sciousness level and } \\
\text { cause of coma. } \\
\text { Sample size: not } \\
\text { calculated }\end{array}$ & $\begin{array}{l}20 \text { patients } \\
\text { Case: HQR for } 15 \\
\text { minutes daily for } \\
4 \text { weeks. } \\
\text { Control: Not } \\
\text { mentioned }\end{array}$ & $\begin{array}{l}\text { Yasiin } \\
\text { played by } \\
\text { MP3, via } \\
\text { head- } \\
\text { phone }\end{array}$ & $\begin{array}{l}\text { BP, HR, RR, } \\
\text { body tempera- } \\
\text { ture } \\
\text { Arterial oxygen } \\
\text { pressure (No A- } \\
\text { a gradient or } \\
\text { PF ratio) } \\
\text { Monitoring: } \\
\text { Measured in } \\
\text { both groups } \\
\text { before and } \\
\text { after interven- } \\
\text { tion. }\end{array}$ & $\begin{array}{l}\text { The mean sBP } \\
{[P=0.04] \text { and } d B P} \\
{[P=0.05], H R} \\
{[P=0.001] \text { and }} \\
\text { arterial oxygen } \\
\text { pressure }[P=0.04] \\
\text { had significant } \\
\text { differences in } \\
\text { comparison with } \\
\text { before intervention. } \\
\text { The difference was } \\
\text { not statistically } \\
\text { significant for RR } \\
\text { and temperature. } \\
\\
\text { Playing the HQR led } \\
\text { to the balance in } \\
\text { blood pressure and } \\
\text { arterial oxygen } \\
\text { pressure of patient }\end{array}$ \\
\hline
\end{tabular}




\begin{tabular}{|c|c|c|c|c|c|c|}
\hline & $\begin{array}{l}\text { First author, } \\
\text { Publication } \\
\text { year }\end{array}$ & $\begin{array}{l}\text { Type of study, } \\
\text { Population and } \\
\text { sampling }\end{array}$ & $\begin{array}{l}\text { Intervention } \\
\text { and comparison }\end{array}$ & Tool & Assessment & $\begin{array}{l}\text { Findings and } \\
\text { Conclusion }\end{array}$ \\
\hline 7. & $\begin{array}{l}\text { MM El-Hady et } \\
\text { al. } 2017^{21} \\
\text { Objectives: To } \\
\text { determine the } \\
\text { religious } \\
\text { intervention } \\
\text { on the level of } \\
\text { comatose } \\
\text { patients. }\end{array}$ & $\begin{array}{l}\text { Design: single } \\
\text { centre, Quasi } \\
\text { experimental. Two } \\
\text { arms. } \\
\text { Feb 2014-July } 2014 \\
\text { Population: } 3 \text { trauma } \\
\text { ICUs from } 3 \\
\text { university affiliated } \\
\text { hospitals on MV for } \\
\text { at least } 72 \text { h, GCS } \\
9-12 \text { on first day, } \\
\text { stable hemodynamic. } \\
\text { Exclusion: deaf, on } \\
\text { muscle relax- } \\
\text { ant. Sample size: Not } \\
\text { calculated. }\end{array}$ & $\begin{array}{l}60 \text { trauma } \\
\text { patients on } \mathrm{MV} \\
\text { Case: } \mathrm{N}=30, \mathrm{HQR} \\
\text { for } 60 \text { minutes } \\
\text { Control: } \mathrm{N}=30 \text { - } \\
\text { rest in bed for } \\
60 \text { minutes }\end{array}$ & $\begin{array}{l}\text { Quran: Al } \\
\text { Baqarah } \\
\text { James } \\
\text { adaptation } \\
\text { of GCS }\end{array}$ & $\begin{array}{l}\text { Physiological: } \\
\text { HR, RR, BP, } \\
\text { CVP, SpO } \\
\text { Monitoring: } \\
\text { Parameters } \\
\text { taken at base- } \\
\text { line, then im- } \\
\text { mediately af- } \\
\text { ter, } 10,20,30 \\
\text { minutes post } \\
\text { intervention. } \\
\\
\text { JGCS, pupil } \\
\text { size, and pupil } \\
\text { reaction }\end{array}$ & $\begin{array}{l}\text { Significant differ- } \\
\text { ences of HR, RR, BP } \\
\text { and use of } \\
\text { accessory muscles } \\
\text { in intervention } \\
\text { group. } \\
\text { Significant increase } \\
\text { in GCS and pupil } \\
\text { reaction to light } \\
\text { immediately after } \\
\text { listening to Quran } \\
\text { (Mean } \pm \text { SD } \\
12.86 \pm 0.68 \text { ) } \\
\text { HQR is an effective } \\
\text { intervention for } \\
\text { improving } \\
\text { hemodynamic, } \\
\text { respiratory } \\
\text { functions and level } \\
\text { of consciousness. }\end{array}$ \\
\hline 8. & $\begin{array}{l}\text { JS Rustam et } \\
\text { al. } 2017^{23} \\
\text { Objectives: To } \\
\text { determine the } \\
\text { effects of } \\
\text { comfort care } \\
\text { integrated } \\
\text { with HQR on } \\
\text { comfort in } \\
\text { muslim pa- } \\
\text { tients on } \mathrm{MV}\end{array}$ & $\begin{array}{l}\text { Design: Pilot study, } \\
\text { quasi-experimental } \\
\text { study, single arm, } \\
\text { pretest-posttest. } \\
\text { Two public hospitals } \\
\text { from Dec } 2016 \text { to Feb } \\
2017 . \\
\text { Population: } 10 \text { ICU } \\
\text { patients on MV, >18 } \\
\text { yo, fully conscious, } \\
\text { no hearing problem, } \\
\text { hemodynamic stable, } \\
\text { no mental disorders. } \\
\text { Exclusion: receiving } \\
\text { continuous sedation, } \\
\text { IV analgesics } \\
\text { Sample size: not } \\
\text { calculated }\end{array}$ & $\begin{array}{l}\text { Single arm of } 10 \\
\text { ICU patients on } \\
\text { MV } \\
\text { HQR for } 15 \\
\text { minutes daily for } \\
3 \text { days }\end{array}$ & $\begin{array}{l}\text { Quran: } \\
\text { Surah Al } \\
\text { Fatihah and } \\
\text { Yassin by } \\
\text { MP3 via } \\
\text { head- } \\
\text { phones. } \\
\\
\text { Modified } \\
\text { version of } \\
\text { shortened } \\
\text { general } \\
\text { comfort } \\
\text { question- } \\
\text { naire } \\
\text { (SGCQ) to } \\
\text { evaluate } \\
\text { comfort }\end{array}$ & $\begin{array}{l}\text { Mean score of } \\
\text { each context of } \\
\text { comfort: } \\
\text { physical, } \\
\text { psychospiritual, } \\
\text { environmental } \\
\text { and } \\
\text { sociocultural }\end{array}$ & $\begin{array}{l}\text { Mean score SGCQ } \\
\text { increased } \\
\text { significantly after } \\
\text { receiving the } \\
\text { comfort care } \\
\text { integrated with } \\
\text { Quran. The mean } \\
\text { score of each } \\
\text { context also } \\
\text { increased } \\
\text { significantly } \\
\text { post-intervention. }\end{array}$ \\
\hline 9. & $\begin{array}{l}\text { Najafi Z et al. } \\
2014^{24} \\
\text { Objectives: To } \\
\text { investigate the } \\
\text { effect of } \\
\text { simultaneous } \\
\text { aromatherapy } \\
\text { and quran } \\
\text { recitation on } \\
\text { anxiety levels } \\
\text { of patients } \\
\text { with } \\
\text { myocardial } \\
\text { infarction }\end{array}$ & $\begin{array}{l}\text { Randomized } \\
\text { controlled trial, } \\
\text { single centre, two } \\
\text { arms } \\
\text { Population: } 70 \\
\text { critically ill patients } \\
\text { in coronary ICU } \\
\text { Not on MV } \\
\text { Sample size: not } \\
\text { calculated. }\end{array}$ & $\begin{array}{l}\text { Case: } \mathrm{N}=35 \text {; } \\
\text { Quran recitation } \\
\text { and lavender } \\
\text { aroma therapy. } \\
\text { HQR } 4 \text { times per } \\
\text { day for } 2 \text { days. } \\
\text { Control: } \mathrm{N}=35 \text {; } \\
\text { no intervention }\end{array}$ & $\begin{array}{l}\begin{array}{l}\text { Quran } \\
\text { recitation }\end{array} \\
\text { Lavender } \\
\text { aroma } \\
\text { Spielberger } \\
\text { anxiety } \\
\text { question- } \\
\text { naire (SAQ) }\end{array}$ & $\begin{array}{l}\text { Anxiety level: } \\
\text { at beginning } \\
\text { and end of } \\
\text { intervention } \\
\text { cycle. }\end{array}$ & $\begin{array}{l}\text { Significant } \\
\text { differences in SAQ } \\
\text { score of } \\
\text { experimental group } \\
\text { and control group } \\
\text { after intervention } \\
\text { in every four cycle. } \\
\text { Simultaneous } \\
\text { aromatherapy and } \\
\text { Quran recitation } \\
\text { reduces the anxiety } \\
\text { level of patients } \\
\text { suffering from myo- } \\
\text { cardial infarction; } \\
\text { hence it can be } \\
\text { used as a useful } \\
\text { technique in } \\
\text { reducing anxiety. }\end{array}$ \\
\hline
\end{tabular}

Legend: HQR=Holy Quran recitation, RCT=randomised controlled trial, RBSI=rapid breathing shallow index, NIF=Negative inspiratory force, $\mathrm{PS}=$ Pressure support, $\mathrm{VT}=$ tidal volume, $\mathrm{CCU}=$ coronary care unit, $\mathrm{MV}=$ minute ventilation, $\mathrm{HR}=$ heart rate, $\mathrm{SBP}=\mathrm{systolic}$ Blood Pressure, $\mathrm{dBP}=$ diastolic blood pressure, $\mathrm{MBP}=$ mean blood pressure, $\mathrm{RR}=$ respiratory rate, $\mathrm{GCS}=\mathrm{Glasgow}$ coma scale. 


\section{ACKNOWLEDGEMENTS}

The study was partly funded by the IIUM Research Intiative Grant Scheme RIGS17-017-0592.

\section{REFERENCES}

1. Chlan BL, Halm MA. Does music ease pain and anxiety in the critically ill? Am J Crit Care. 2013;22:528-533.

2. Lusk B, Lash AA. The stress response, psychoneuroimmunology, and stress among ICU patients. Dimens Crit Care Nurs. 2005;24(1):2531.

3. Aghaie B, Rejeh N, Heravi-Karimooi M, et al. Effect of nature-based sound therapy on agitation and anxiety in coronary artery bypass graft patients during the weaning of mechanical ventilation: A randomised clinical trial. Int $\mathrm{J}$ Nurs Stud. 2014;51:526-538.

4. Devlin JW, Skrobik Y, Gélinas C, et al. Clinical Practice Guidelines for the Prevention and Management of Pain, Agitation/Sedation, Delirium, Immobility, and Sleep Disruption in Adult Patients in the ICU. Crit Care Med. 2018;46:e825-e873.

5. Chlan LL, Weinert CR, Heiderscheit A, et al. Effects of patient-directed music intervention on anxiety and sedative exposure in critically III patients receiving mechanical ventilatory support: A randomized clinical trial. JAMA. 2013;309:2335-2344.

6. Anastasi MW, Newberg AB. A Preliminary Study of the Acute Effects of Religious Ritual on Anxiety. J Altern Complement Med. 2008;14:163 $-165$.

7. Rath LL. Intercessory prayer as an intervention for stress in critically-ill neonates. South Online J Nurs Res. 2008;8:2p.

8. Fisher P. Introduction of meditation to meet service users ' spiritual needs. Ment Heal Pract. 2011;14:p33.

9. Levin JS, Chatters LM. Research on religion and mental health: An overview of empirical findings and theoretical issues. In: Handbook of Religion and Mental Health. ; 1998:33-50.

10. Sahmeddini MA, Lari MZ, Rahimian MN, Danaei L, Beigi N, Habibi $\mathrm{H}$. The effect of listening to the Quran on serum cortisol levels and anxiety in primiparous women during the first stage of labor. Iran J Obs Gynecol Infertil. 2014;17:1-7.

11. Frih B, Mkacher W, Bouzguenda A, et al. Effects of listening to Holy Qur'an recitation and physical training on dialysis efficacy, functional capacity, and psychosocial outcomes in elderly patients undergoing haemodialysis. Libyan $J$ Med. 2017;12:1372032.

12. Babaii A, Abbasinia M, Hejazi SF, Reza S, Tabaei $S$, Dehghani $F$. The Effect of Listening to the Voice of Quran on Anxiety before Cardiac Catheterization: A Randomized Controlled Trial. Heal Spiritual Med Ethics. 2015;2:8-14.

13. Allameh $\mathrm{T}$, JabalAmeli M, Lorestani K, Akbari M. The efficacy of quran sound on anxiety and pain of patients under cesarean section with regional anaesthesia: A randomized case-controlled clinical trial. J Isfahan Med Sch. 2013;31:601. 610.

14. Ghiasi A, Keramat A. The Effect of Listening to Holy Quran Recitation on Anxiety: A Systematic Review. Iran J Nurs Midwifery Res. 2018;23:411420.

15. Higgins JPT, Sterne JAC, Savović J, Page MJ, Hróbjartsson A, Boutron I, Reeves B ES. A revised tool for assessing risk of bias in randomized trials. Cochrane Database Syst Rev. 2016;10:1-4.

16. Ariff M, Ashikin M, Maryamjameelah R, Bushra J, Wan Azman WA. Pilot Study on the Effect of Yasiin Recitation on the Haemodynamics of Ventilated Patients. Int Med J Malaysia. 2013;12:45-49.

17. Abu Bakar SA. Effect of Holy Quran listening on physiological stress response among Muslim patients in the intensive care unit. J Manag Muamalah. 2014;5:164-173.

18. Yadak M, Ansari KA, Qutub H, et al. The Effect of Listening to Holy Quran Recitation on Weaning Patients Receiving Mechanical Ventilation in the Intensive Care Unit: A Pilot Study. J Reli Heal. 2017;Sep 30:1-10.

19. Naseri-salahshour V, Varaei S, Sajadi M, Tajdari $S$, Sabzaligol M, Fayazi N. The effect of religious intervention on the level of consciousness of comatose patients hospitalised in an intensive care unit: a randomised clinical trial. Eur $J$ Integr Med. 2018;21:53-57.

20. Nasiri AA, Shahdadi H, Mansouri A, Bandani E. An Investigation into the Effect of Listening to the Voice of the Holy Quran on Vital Signs and Consciousness Level of Patients Admitted to the ICU Wards of Zabol University of Medical Sciences Hospitals. Middle East J Fam Med. 
2017;15:75-79.

21. El-hady MM, Kandeel NA. The Effect of Listening to Qur' an on Physiological Responses of Mechanically Ventilated Muslim Patients. IOSR J Nurs Heal Sci. 2017;6:79-87.

22. Mirzaeian R, Shirvani $M$, Alidosti $M$. The effect of Holy Quran recitation sound on vital signs and arterial oxygen pressure of uncconscious patients hospitalised in ICU. IAJPS. 2017;4:1254 $-1259$.

23. Rustam JS, Kongsuwan W, Kitrungrote L. Effect of Comfort Care Integrated with the Holy Qur' an Recitation on Comfort of Muslim Patients under Mechanical Ventilationa: A Pilot Study. Med Surg Nurs J. 2017;6:34-40.

24. Najafi Z, Tagharrobi Z, Taghadosi M, Sharifi K, Farrokhian A. The effect of simultaneous aromatherapy and Quran recitation on anxiety level of patients with myocardial infarction. Complement Med J. 2014;4:700-712.

25. Jabbari B, Mirghafourvand M, Sehhatie F, Mohammad-Alizadeh-Charandabi S. The Effect of Holly Quran Voice With and Without Translation on Stress, Anxiety and Depression During Pregnancy: A Randomized Controlled Trial. J Relig Health. 2017;30 May:1-11.

26. Nakhavali F, Seyedi SH. A Research on "Rhythm \& Music" in the Quran. Int J Linguist. 2013;5:21 -27 .

27. Mahjoob M, Nejati J, Hosseini A, Bakhshani NM. The Effect of Holy Quran Voice on Mental Health. J Relig Health. 2016;55:38-42.

28. Moghaddam F, Bousarri MP, Faghihzadeh S, Masoumi N. Effect of Auditory Stimulation by Family Voices and Recitation of $\backslash \mathrm{nPrayers}$ on Hemodynamic Changes in Comatose Patients: A Clinical Trial With Control Group. Crescent J Med Biol Sci. 2016;3:60-66.

29. Deuraseh N, Mohd Tohar SNA. Healing Through Ruqyah (incantation) With Special Focus on the Perception of Malay-Muslim Society in Kelantan and Terengganu on Ruqyah as an Alternative Way of Healing in Malaysia. J Int Soc Hist Islam Med. 2008;7:50-54.

30. Al-Galal SAY, Alshaikhli I, Rahman A, Dzulkifli M. EEG-based emotion recognition while listening to Quran recitation compared with relaxing music using valence-arousal model. In: 2015 4th International Conference on Advanced Computer Science Applications and Technologies, Kuala Lumpur. ; 2015:245-250.

31. Shekha MS. Effects of Quran Listening and Music on Electroencephalogram Brain Waves. Egypt J Exp Biol. 2013;9:7.

32. Zulkurnaini N, Abdul Kadir R, Murat Z, Mohd Isa $\mathrm{R}$. The comparison between listening to $\mathrm{Al}$ -Quran and listening to classical music on the brainwave signal for the alpha band. In: $3 r d$ International Conference on Intelligent Systems Modelling and Simulation. ; 2012:181-186.

33. Davis A, Gimenez A. Cognitive-behavioral recovery in comatose patients following auditory sensory stimulation. J Neurosci Nurs. 2003;35:202-209.

34. Park S, Davis AE. Effectiveness of direct and non -direct auditory stimulation on coma arousal after traumatic brain injury. Int $J$ Nurs Pract. 2016;22:391-396.

35. Oh H, Seo W. Sensory stimulation programme to improve recovery in comatose patients. $\mathrm{J}$ Clin Nurs. 2003;12:394-404.

36. Konkani A, Oakley B. Noise in hospital intensive care units-a critical review of a critical topic. $J$ Crit Care. 2012;27:522.e1-522.e9. 